\title{
The unwitting pioneer of transatlantic format adaptation: Beryl Vertue
}

Article

Accepted Version

Knox, S. (2019) The unwitting pioneer of transatlantic format adaptation: Beryl Vertue. Historical Journal of Film, Radio and Television, 39 (2). pp. 341-365. ISSN 0143-9685 doi: https://doi.org/10.1080/01439685.2018.1522790 Available at https://centaur.reading.ac.uk/77128/

It is advisable to refer to the publisher's version if you intend to cite from the work. See Guidance on citing.

To link to this article DOI: http://dx.doi.org/10.1080/01439685.2018.1522790

Publisher: Taylor \& Francis

All outputs in CentAUR are protected by Intellectual Property Rights law, including copyright law. Copyright and IPR is retained by the creators or other copyright holders. Terms and conditions for use of this material are defined in the End User Agreement.

\section{www.reading.ac.uk/centaur}

\section{CentAUR}

Central Archive at the University of Reading

Reading's research outputs online 


\section{THE UNWITTING PIONEER OF TRANSATLANTIC FORMAT ADAPTATION: BERYL VERTUE}

Simone Knox, University of Reading

Postal address:

University of Reading

Department of Film, Theatre \& Television

Minghella Studios

Shinfield Road

Reading, Berkshire

RG6 6BT.

Telephone number:

01183784076

Email address:

s.knox@ reading.ac.uk

Biographical note:

Dr Simone Knox is Lecturer in Film and Television at the University of Reading. Her research interests include the transnationalisation of film and television (including audio-visual translation), aesthetics and medium specificity (including convergence culture, and acting and performance), and representations of minority identities, as well as the lived experience of screen culture. She sits on the board of editors for Critical Studies in Television and her publications include essays in Film Criticism, Journal of Popular Film and Television and New Review of Film and Television Studies, as well as the co-authored blog strand 'What Actors Do' for CSTOnline.

ORCID: 0000-0002-5094-6203

Twitter: @simoneknox 


\begin{abstract}
This article explores the transatlantic work of Beryl Vertue (b. 1931), whose distinguished career includes selling the format for Till Death Us Do Part (BBC1, 1965-1975) and Steptoe and Son (BBC1, 1962-1974) to American television, as well as producing the Upstairs, Downstairs format adaptation Beacon Hill (CBS, 1975) in the USA. I map how her crucial involvement in the genesis of All in the Family (CBS, 1971-1979) and Sanford and Son (NBC, 1972-1977) has been neglected in existing accounts, which have tended to focus on Norman Lear. I contrast these with Vertue's own recollection, drawing out her role in the creation of these two seminal programmes. I then locate Vertue within a broader transatlantic movement of British television production personnel during the 1970s. I explore Vertue's decision-making process for Beacon Hill, a programme that deserves a more prominent place in accounts of US television history, not least because of its connections to discourses on quality. I uncover how her creative agency was informed by her difference and productive Otherness whilst also subject to tensions and limitations present within complex industrial structures. Informed by an original in-depth interview with Vertue, the article considers her an unwitting pioneer of transatlantic format adaptation.
\end{abstract}

\title{
Keywords
}

FORMAT ADAPTATION; BERYL VERTUE; TILL DEATH US DO PART; ALL IN THE FAMILY; STEPTOE AND SON; SANFORD AND SON; NORMAN LEAR. UPSTAIRS, DOWNSTAIRS; BEACON HILL; CBS; FRED SILVERMAN. 


\section{THE UNWITTING PIONEER OF TRANSATLANTIC FORMAT ADAPTATION: BERYL VERTUE}

This article arises from an interest in how the history of British and US television has been shaped by the movement of production personnel across the Atlantic. There is a long line of individuals who have worked in both British and North American television. Personnel flow from the USA and Canada to the UK has been shaped by contextual factors, such as Cold War McCarthy blacklisting in Hollywood and a need for trained staff in the expanding British television market leading to a wave of US and Canadian émigrés working for British television in the $1950 \mathrm{~s}^{1}{ }^{1}$ The list of television personnel headed Westwards includes some of the biggest names of British television drama production, such as Martin Campbell, Dick Clement and Ian La Frenais, Michael Grade and Verity Lambert. Such individuals have generally been attracted by the history, glamour and professional opportunities Hollywood offers, but their movement has also been shaped by historically contingent contexts, bearing significant nuances.

Interested in uncovering such nuances, this article's focus of investigation lies with the transatlantic work of British television producer Beryl Vertue (b. 1931). To give a brief overview of her significant contribution to British and American television, Vertue began as an agent who, after joining the Robert Stigwood Organisation (RSO) in 1967, sold comedy scripts and formats across Europe and then the format of Till Death Us Do Part (BBC1, 1965-1975) and Steptoe and Son (BBC1, 1962-1974) to the USA, which resulted in the transatlantic adaptations All in the Family (CBS, 1971-9179) and Sanford and Son (NBC, 1972-1977). Within Britain, she sold Upstairs, Downstairs (ITV, 1971-1975) to London Weekend for Associated London Films in 1970. Towards the mid-1970s, Vertue went to the USA to produce Upstairs, Downstairs format adaptation Beacon Hill (CBS, 1975), comedy game show adaptation Almost Anything Goes (ABC, 1975-1976), and several TV movies including The Entertainer (NBC, 1976). Following her return to the UK, she produced The Prime of Miss Jean Brodie (1978) before setting up her own independent production company, Hartswood Films, during the 1980s. Hartswood Films has produced Men Behaving Badly (ITV/BBC1, 1992-1999) and Coupling (BBC2, 2000-2004), both of which have had unsuccessful US adaptation attempts (NBC, 1996-1997 and NBC 2003). Its roster further includes Sherlock (BBC1, 2010present), an international co-production with WGBH co-created by Vertue's son-inlaw Steven Moffat and produced by her daughter, Sue Vertue. With such an extensive career, my discussion will necessarily be selective and focus on Vertue's extensive dealings with US television production in the 1970s.

For her significant contribution to television, of which the above is merely a brief sketch, Beryl Vertue has received numerous honours within the British creative industry, but, as I will demonstrate, not much attention within the scholarly study of television. To help address this gap, my analysis will draw on an original, in-depth interview with Vertue, conducted on 4 December 2012 in her office at Hartswood Films, then located at Twickenham Studios. ${ }^{2}$ Inevitably, interviews are marked by

\footnotetext{
${ }^{1}$ See Steve Neale, Pseudonyms, Sapphire and Salt: 'Un-American' contributions to television costume adventure series in the 1950s, Historical Journal of Film, Radio and Television, 23, no. 3 (2003), 245257.

${ }^{2}$ All subsequent quotations from Vertue are from this interview, unless otherwise indicated.
} 
issues of subjectivity, memory and selectivity. As Williams puts it, '[i]nterviews generate material that is [...] interpretative and richly interpretable. ${ }^{3}$ Mills points out that 'it is important to acknowledge the subjectivity within any interview material, and not to use this data as evidence of certain kinds of working practices. ${ }^{4}$ However, as Ritchie has argued, '[o]ral history is as reliable or unreliable as other sources' ${ }^{5} \mathrm{He}$ has further noted that '[a]s a result of [...] blind spots, oral history can develop information that might not have appeared in print. ${ }^{9}$ This seems especially apt for engagement with Vertue's work, given the ephemeral nature of much of the television production culture she has been part of, as well as the fact that she has been quite neglected within existing scholarship. If oral history has the potential to 'give back to the people who made and experienced history, through their own words, a central place', then Beryl Vertue deserves to come to occupy such a place. ${ }^{7}$

My discussion frames, contextualises and interrogates Vertue's interview testimony with my own critical commentary, locating her specific experience within a wider historically contingent context and pattern, with references to relevant comparable examples (such as Sydney Newman and Tony Garnett). Understanding Vertue's words as 'cultural artifacts containing evidence of an intricate, interlocking system of heavily codified, discursive knowledge', I wanted to gain insights into her subjective experience and personal views, to capture the insider knowledge of a practitioner who has seminal transatlantic professional experience. ${ }^{8}$ This article argues that Beryl Vertue should be understood as an unwitting pioneer of transatlantic fiction format adaptation, firstly because she sold the formats for two significant US programmes (All in the Family and Sanford and Son) and secondly because she produced a format adaptation (Beacon Hill) that deserves to be uncovered from the mists of US television history. Intending to give due credit to Vertue's input into and impact on broadcasting and television production, I am simultaneously interested in uncovering the tensions and limitations that have affected her creative agency and working practices, as Vertue has operated within complex professional networks and institutional/industrial structures and hierarchies.

\section{Not just Norman Lear: Challenging the Origins Stories of All in the Family and Sanford and Son}

The cultural significance of All in the Family and Sanford and Son is widely established. For example, Gunzerath has remarked that

All in the Family's lasting impact on American television is difficult to

\footnotetext{
${ }^{3}$ Linda Ruth Williams, Speaking of Soft Core, Cinema Journal, 47, no. 2 (2008), 134.

${ }^{4}$ Brett Mills, After the Interview, Cinema Journal, 47, no. 2 (2008), 152.

${ }^{5}$ Donald A. Ritchie, Doing Oral History: A Practical Guide, second edition (Oxford, Oxford University Press, 2003), 26.

${ }^{6}$ Ritchie, Doing Oral History, 26.

${ }^{7}$ Paul Thompson, The Voice of the Past: Oral History, third edition (Oxford, Oxford University Press, 2000), 3. Vertue has previously been interviewed for a few scholarly and popular publications. See Richard Marson, Inside Updown: The Story of Upstairs, Downstairs (Dudley, Kaleidoscope Publishing, 2011 [2001]); Brett Mills, The Sitcom (Edinburgh, Edinburgh University Press, 2009); Ian Potter, The Rise and Rise of The Independents: A Television History (Isleworth, Guerilla Books, 2008); and Jean K. Chalaby, Drama without Drama: The Late Rise of Scripted TV Formats, Television \& New Media, 17, no. 1 (2016), 3-20.

${ }^{8}$ Denise Mann, It's Not TV, It's Brand Management TV: The Collective Author(s) of the Lost Franchise, in Production Studies: Cultural Studies of Media Industries, ed. Vicki Mayer, Miranda J. Banks and John T. Caldwell (New York; London, Routledge, 2009), 105.
} 
overestimate. It helped to usher in a new generation of comedic programs that abandoned the light domestic plotlines of television's early years in favor of topical themes with important social significance. In this sense, its influence on prime-time programming continues to be felt decades later. ${ }^{9}$

Similarly, Lentz has argued that 'relevant' sitcoms including All in the Family and Sanford and Son

ignited a massive, nationwide discussion about the appropriate modes of representing race and racism. These shows are therefore widely regarded as having significantly influenced - for better or worse - the history of racial representations. ${ }^{10}$

Moreover, All in the Family and Sanford and Son spawned several spin-offs, including, for the former, Maude (CBS, 1972-1978), from which itself Good Times (CBS, 1974-1979) was spun off, and The Jeffersons (CBS, 1975-1985). ${ }^{11}$ So, in addition to their cultural significance, these two programmes also had a considerable impact on the US television landscape and the sitcom genre.

Unsurprisingly, a good amount of critical literature has explored the genesis of both of these shows - however, Vertue's name is noticeable for its absence, as the following extracts from earlier accounts demonstrate. For example, in their 1995 discussion of the work of Norman Lear, Marc and Thompson noted:

Lear contemplated a daring return to prime-time television that would ignore the conventional wisdom of providing audiences with what insiders called "least objectionable" programming. His idea was to do an American adaptation of a British sitcom, Johnny Speight's Till Death Us Do Part, which had been built around the generational conflicts between a bigoted middleaged man and his live-in son-in-law. He tried to sell the innovative concept to ABC in 1968, but the network honchos were too timid to make a deal, despite the fact that $\mathrm{ABC}$, as the last-place network, had relatively little to lose.

Paradoxically, it was CBS, the top-rated network, that was more receptive to Lear's proposal. ${ }^{12}$

This bears much congruence with Bedell's account of the genesis of All in the Family in her 1981 biography of Fred Silverman:

[CBS programmer Marc Golden] was howling with laughter because he had spotted an episode of the British Broadcasting Corporation's smash-hit comedy Till Death Us Do Part. [...] Golden carried home an episode [...] and showed it to his colleagues in New York. They termed it brilliant. Programming vice-president Irwin Segelstein suggested that an American version with CBS star Jackie Gleason might work well. [CBS television programming executive Mike] Dann was intrigued enough to authorize CBS

\footnotetext{
${ }^{9}$ David Gunzerath, All in the Family, in Museum of Broadcast Communications Encyclopedia of Television Volume 1 A-C, second edition, ed. Horace Newcomb (New York, Fitzroy Dearborn, 2004), 59.

${ }^{10}$ Kirsten Marthe Lentz, Quality versus Relevance: Feminism, Race, and the Politics of the Sign in 1970s Television, Camera Obscura, 43, 15, no. 1 (2000), 46.

${ }^{11}$ Maude was adapted for British television as Nobody's Perfect (ITV, 1980-1982), and Good Times as The Fosters (ITV, 1976-1977), making the latter a format adaptation of a spin-off of a spin-off of a format adaptation and thus a vivid example of the complexity of transatlantic television relations. ${ }^{12}$ David Marc and Robert J. Thompson, Prime Time, Prime Movers: From I Love Lucy to L.A. LawAmerica's Greatest TV Shows and the People Who Created Them (Syracuse, N. Y., Syracuse University Press, 1995), 51.
} 
to buy the rights to the British show. But the CBS executives lost out to a balding, slightly built comedy writer and film director named Norman Lear. He had read about the British series in TV Guide magazine and been instantly reminded of his stormy relationship with his own father. Without even seeing an episode or reading a script, he sealed a deal for an American adaptation. ${ }^{13}$ As far as the inception of Sanford and Son is concerned, McCrohan suggested in 1990 that:

Steptoe and Son had been tried earlier on U.S. television; actors Lee Tracy and Aldo Ray made a pilot that didn't sell. Norman Lear bought the rights, then made another pilot, with Barnard Hughes and Paul Sorvino. It wasn't picked up either. Then came the inspiration to cast black actors and to make them junkmen in the highly topical black ghetto of Watts, Los Angeles. ${ }^{14}$

Within more recently published scholarship, the focus on the input and agency of a (by now sizeable) number of male television personnel continues. For example, referring to Lear as the initiator of US-UK remakes, Ducray comments that: [...] in 1971, he tried to sell the idea of a blue-collar sitcom to ABC, which rejected it, arguing it would not suit its viewers' tastes. Norman Lear then changed strategy and approached CBS with an adaptation of Till Death Us Do Part [...]. [...] Norman Lear decided to develop the race relations theme by adapting a second 'Britcom,' Steptoe and Son [...]. In Sanford and Son [...], he used the same ingredients as in his first remake, i.e. transposing foreign cultural motives into local ones to produce an endemic situation. A significant novelty was introduced: the white English junk dealers had become AfricanAmericans. ${ }^{15}$

Similarly, Martens' discussion of the African Americanisation of Steptoe and Son considers the conception of its US adaptation repeatedly and only in relation to Lear's and his producing partner Bud Yorkin's work and intentions. ${ }^{16}$ Meanwhile, Buonomo importantly notes an element of complexity concerning the exporting of Till Death Us Do Part's format, namely that before it was sold to the USA, it had first 'caught the attention of television producers and writers in other countries [...]. Thus, more or less revised versions of Alf Garnett and family appeared in the Netherlands, Israel, Brazil and Germany [...]. ${ }^{17}$ What Buonomo here points to - albeit without mentioning her name - is that Vertue sold the formats for a number of projects in Europe, including Steptoe and Son to Holland, which resulted in Stiefbeen en Zoon

\footnotetext{
${ }^{13}$ Sally Bedell, Up the Tube: Prime-Time TV and the Silverman Years (New York, The Viking Press, 1981), 40-41. Marc's account of the genesis of All in the Family adds another male name to the mix of television personnel, when he notes that after ABC turned it down, 'Lear went next to CBS, where he found a friendly patron in network president Robert Wood.' David Marc, Comic Visions: Television Comedy and American Culture (Winchester, MA, Unwin Hyman, 1989), 175.

${ }^{14}$ Donna McCrohan, Prime Time, Our Time: America's Life and Times Through the Prism of Television (Rocklin, CA, Prime Publishing \& Communications, 1990), 225.

${ }^{15}$ Amandine Ducray, Sharing the Joke? 'Britcom' Remakes in the United States: A Historical and Socio-Cultural Perspective, InMedia 1 (2012), http://inmedia.revues.org/132. Ducray briefly refers to Vertue in relation to the latter's experience of the remaking of Men Behaving Badly and political correctness.

${ }^{16}$ James W. Martens, Come On Over! The African Americanization of Steptoe and Son, in American Remakes of British Television: Transformations and Mistranslations, ed. Carlen Lavigne and Heather Marcovitch (Plymouth, Lexington Books, 2011).

${ }^{17}$ Leonardo Buonomo, The Americanization of a Bigot: From Till Death Us Do Part To All In The Family, Revista de Estudios Norteamericanos, 16 (2012), 31.
} 
(NCRV, 1963-1971). Buonomo then proceeds to note what should be becoming a familiar tale to the reader, namely that Lear bought the rights to the series without having watched a single episode.

Finally, Lear's autobiography resonates with much of the historical accounts cited above. Noting the strong personal connection he felt when reading about Till Death Us Do Part, Lear's recollection includes Vertue, but only in a single sentence: 'Between early August and the end of September 1968, we secured the rights to the show from its British rep, Beryl Vertue, ABC commissioned a pilot, and I wrote and cast the episode. ${ }^{18}$ His brief attention to Sanford and Son makes no mention of her.

Individually and collectively, these accounts provide a number of insights into a significant moment in the development of US television and USA-UK format trading. However, compare these accounts to Vertue's recollection of events - and given how entrenched the absence of her name is from the above accounts, it is worth quoting her at length:

So [...] then I thought, I ought to try America now! I'd sold a film idea, which had involved an American company [Joseph E. Levine's Embassy Pictures], which we then produced here, but this American company then formed a television arm, and I thought I'll show it to them. They made a pilot for an American network; I was nothing to do with it, I had sold the idea. When I saw it, it was really awful and I realised then - and they only made a pilot, it didn't get commissioned for a series. It was for a comedy series called Steptoe and Son, and it was just really, really wrong and it made me realise that the people who had done it didn't understand what had made the idea work in the first place, and that's what you have to understand. You can adapt it, but what is the core of what made it work in the first place - they hadn't seen that.

Steptoe and Son is about a father and son who need each other, but who won't admit it, and the son is trying to get out of the environment and the father is trying to stop him; and they were rag and bone men. In America they don't have rag and bone men, but they have junk, which I had to remind them about. They said, 'We don't have rag and bone men', and I said, 'Do you have junk?' They said, 'Yes', so I said, 'Well that's what it is then, that's what they're selling.' They didn't have a horse and cart, they had a van, that was fine; but they lived in a lovely apartment! I said, 'Why would he want to leave this environment? It's all really, really nice.' So the whole thing was wrong; so I learned from that; whoever it was in charge had to understand what's at the core. So I put that in a drawer, and then after some time I decided I would try America with Till Death Us Do Part. [...]

So there you've got religion and bigotry and controversy, all those things [...] and so I said to Johnny Speight that I was going to America to try to sell this thing, indeed we'd already got a bit of interest from CBS network. So I said, 'If I don't think it's going to be right, do you mind if we don't sell it at all?' So he said, 'No, you do what you think best.' So I went off with that mandate; so I went to CBS and the first person I met, who took me out to lunch, was the lawyer. So he said something about the money and I went, 'No, no, no',

\footnotetext{
${ }^{18}$ Norman Lear, Even This I Get to Experience (New York, The Penguin Press, 2014), 221.
} 
whereupon he promptly put the money up! I said 'No, I don't want to talk about the money, I want to talk about the programme and who will be doing it.' So that ended with us going back to the office and all sorts of people kept joining this meeting, thinking I was being difficult, I think. I said this programme is really controversial, and they said they had a series in America called The Smothers Brothers. They said, 'We are very used to controversy.' So I said, 'Well, I've seen that show and I thought it was very good and very pleasant,' - was the word I used, 'but,' I said, 'it absolutely isn't controversial.' And I said, 'If you make this programme as you should make it, you'll have a nervous breakdown if you think that [The Smothers Brothers] is controversial.' So I said, 'I really am sorry, I can't sell it here, because I can't sell it to a building. ${ }^{19}$

I couldn't see who was going to be in charge; it was all executive, nobody creative was going to be doing it. So I left, but then while I was there I was introduced, through an agent, to a man called Norman Lear and he'd heard about this programme too, so he was rather keen to meet and so it's probably true to say I auditioned him; I was so sure and so determined I was going to get it right while I was there, that we met every day, all that week, and talked about the programme. So we talked about it a great deal, and in the end, I thought, if this man doesn't get it right, I don't know who would. He seemed to be the American equivalent of Johnny Speight: a good writer, brave, a bit of a maverick, all those things. So he bought the format and made a huge hit with it. [...] Some of it I didn't understand, and that was interesting, that was where he got it so right; he took their prejudices, their bigotry. There was one bit about 'spicks', and I said, 'I don't know what a spick is' and he said, 'It's Puerto Rican', and still that didn't mean anything to me, but it did to Americans.

[...] So after a time, I said to Norman Lear, 'I've got something else to show you.' I opened the drawer and I got out Steptoe and Son, and I said, 'The writers and I thought it would be quite good if they were black', and he said that's what he was thinking as well and they cast it with two black people. Redd Foxx was unknown to television, but was an outrageous, very risqué comedian, and Normal Lear, again, did it brilliantly, it was another huge hit, so I was very proud of that and still am, that I managed to sell it to the right person.

Vertue's account certainly provides historical insight and detail concerning the genesis of All in the Family and Sanford and Son that 'might not have appeared in print' otherwise. ${ }^{20}$ It is particularly noteworthy for several reasons: It repeatedly delimits and qualifies the significance of her own input and role, whilst referencing and giving credit to the work of others, especially the importance of the US creative individuals in the success of the adaptations of the formats she was selling. Already hinting at the 'unwitting' in the article title, this is something of a habit for Vertue,

\footnotetext{
${ }^{19}$ As Gitlin notes: 'The same [CBS President] Robert D. Wood who put All in the Family on the air also cancelled the Smothers Brothers show [sic] in 1969 because they wouldn't submit their programs sufficiently ahead of air dates for the Standards and Practices department to screen them.' Todd Gitlin, Inside Prime Time (New York, Pantheon Books, 1985), 206.

${ }^{20}$ Ritchie, Doing Oral History, 26.
} 
who when interviewed by a journalist in the 1970s pointed out that she only started to work as an agent at Associated London Scripts '[m]ainly because there wasn't anyone else to do it. ${ }^{21}$

Indeed, in her own view, her key responsibility and contribution was precisely to find the right person(s) in the USA to sell to, thus intertwining her own work and agency with that of others. What nevertheless emerges from her words is a reaffirmation of the significant role she played: she was closely involved in key points of the decision-making processes at stake, for which she drew on her own knowledge of US and British television and her own judgment, encouraged and trusted by others to 'do what you think is best'. Indeed, the conventional 'Norman Lear narrative' present in the scholarship cited earlier sees an important inflection here in the picture Vertue tells of effectively auditioning Lear, which complicates the dominant ascription of agency in the genesis of All in the Family.

Furthermore, Vertue's words testify to the complex non-linearity of transatlantic format adaptation: in contrast to the striking and simplifying ascription of daring creative vision to Lear in the accounts cited above, Vertue's recollection gives a much stronger flavour of the actual lived experience of television production, with a series of false starts, set-backs and hesitations. This is echoed and confirmed by Lear's recollection; and Vertue's interview testimony and Lear's autobiography together convey a vivid sense of All in The Family's complicated (pre-)production history: the pilot on CBS was preceded not only by the unsuccessful attempt by Joseph E. Levine's production company to adapt Steptoe and Son, but also two unsuccessful attempts by Lear to get the Till Death Us Do Part adaptation green-lit by $\mathrm{ABC}$, involving two title changes (Justice for All and Those Were the Days), some recasting and struggles with CBS's Program Practices department. ${ }^{22}$

Vertue's account attests to the issues and challenges in format adaptation concerning cultural proximity and glocalisation. ${ }^{23}$ It furthermore connects strongly with Navarro's view that an adaptation is a new performance that 'interprets, actualizes, and redefines the format' to make it accessible for and appealing to a new audience. ${ }^{24}$ Moreover, she articulates an acute understanding of the complex pushpull between preserving 'what's at the core' of a programme and making it relevant to a new cultural context, including switching from 'rag and bone' to 'junk', and tapping into the racial discourses of 1970s America.

This resonates with similar arguments made by Chalaby - a welcome exception in the broader scholarly neglect of Vertue's work - who has pointed to the particular challenges involved in the format adaptations for scripted programmes, which are more culturally sensitive than game shows or talent competitions. As he notes:

\footnotetext{
${ }^{21}$ Michael Newberry, How a super secretary struck it rich, Sunday Express, April 23, 1972.

${ }^{22}$ Lear, Even This, 221-239.

${ }^{23}$ See Joseph Straubhaar, Beyond Media Imperialism: Assymetrical Interdependence and Cultural Proximity, Critical Studies in Mass Communication, 8, no. 1 (1991), 39-59; and Roland Robertson, Glocalization: Time-Space and Homogeneity-Heterogeneity, in Global Modernities, ed. Mike Featherstone, Scott Lash and Roland Robertson (London, Sage, 1995).

${ }^{24}$ Vinicius Navarro, More than Copycat Television: Format Adaptation as Performance, in Global Television Formats: Understanding Television Across Borders, ed. Tasha Oren and Sharon Shahaf (London; New York, Routledge, 2012), 25.
} 
It requires a great deal of talent - and a dose of good fortune - to capture the essence of a comedy or drama and make it work in another culture. The local production team must combine knowledge of the principles of scriptwriting with an understanding of the show's vision and core values. This complexity explains $[\ldots]$ why several attempts may be needed to re-version a script, and why some comedies that are TV classics in their countries of origin never travel $[\ldots] .{ }^{25}$

Finally, Vertue offers a fascinating insight into the lived experience of the differences in cultures of production between the UK and the USA, with her references to lunch with the lawyer and not being able to sell a programme format 'to a building' underscoring some of the established conventional ideas concerning corporate American production culture and a traditional British emphasis on creative authorship. Here, some of Vertue's discussion upholds traditional binary oppositions between British and US television production. At the same time, of course, by placing a British woman at the core of the genesis of two programmes so significant to US television and culture, she also problematises these very divisions.

\section{Exceptional and Atypical Work Habitually Neglected}

It is worth reflecting on the discrepancy between the available literature on these influential programmes and Beryl Vertue's account, which underscores how US- and man-centric much of the former has been. These accounts tend to ascribe agency, intent and authorship to the male US television individuals involved, often as part of a dominant 'Norman Lear narrative'. This underscores television historiography's need for a non-Oedipal model of agency. ${ }^{26}$ Certainly, Vertue's name gets neglected to get mentioned, even in passing, far too often in these origins stories. Miller is another welcome exception here, observing that Vertue 'acted as go-between for the BBC and Norman Lear in Lear's acquisition of rights to Till Death Us Do Part and Steptoe and Son. ${ }^{27}$ His choice of word 'go-between' rightly highlights the liminal position of the seller, but does not quite capture the degree of autonomy Vertue's account affords her.

This neglect of Beryl Vertue links to a general historiographical issue, namely that historical erasure is implemented (even unintentionally) through the privileging, repeated articulation and thus reification of certain narratives and identities, producing and reaffirming dominant master narratives that obscure other narratives and identities. This can happen whether there is a critical stance towards those dominant narratives and identities or not - it is not unreasonable to suggest that Bedell, for example, neglects Vertue's name (at least partly) because Fred Silverman is the critical target of her work. However, Vertue's neglect also links to a specifically feminist historiographical issue, pithily identified by Hilmes as follows: 'It is history writing that has consigned women to the sidelines, not historical events themselves. ${ }^{28}$

\footnotetext{
${ }^{25}$ Chalaby, Drama without Drama, 7, emphasis in original.

${ }^{26}$ Jonathan Bignell, And the rest is history: Lew Grade, creation narratives and television historiography, in ITV Cultures: Independent Television Over Fifty Years, ed. Catherine Johnson and Rob Turnock (Maidenhead, Open University Press, 2005), 69.

${ }^{27}$ Jeffrey S. Miller, Something Completely Different: British Television and American Culture (Minneapolis, MN, University of Minnesota Press, 2000), 163.

${ }^{28}$ Michele Hilmes, Radio Voices: American Broadcasting, 1922-1952 (Minneapolis, MN, University of Minnesota Press, 1997), 132.
} 
It is worth noting that Vertue has received more sustained attention and recognition for the importance of her work within press discourses. (Here, past articles often gave recognition to Vertue's achievements whilst simultaneously showing a patronizing preoccupation with the fact that Vertue's work involved high budgets and appropriate financial remuneration. $)^{29}$

As such, my discussion is connected to scholarly endeavours to recognise the work of women in the creative industries, such as the Women's Film \& Television History Network-UK/Ireland. Ball and Bell have noted that: 'The issue of women's role in the production of film and television is poorly understood and subjected to critical silence. ${ }^{30}$ They further point out that a tendency within recent scholarship on women within television has been to 'focus on 'exceptional' women whose experiences are atypical', such as producer Grace Wyndham Goldie or writer Lynda La Plante, which they rightly argue 'limits the relevance of this research to debates about women's wider contribution to production.' ${ }^{31}$ Given the breadth and depth of her career, Vertue is undoubtedly another 'exceptional' woman with therefore 'atypical' experiences. (Indeed, Chalaby notes that 'Beryl Vertue began selling sitcom formats to US TV networks in the 1970s, but her feat was the exception rather than the rule. ${ }^{32}$ The exceptionality here is located by Chalaby in the fact that comedy generally does not travel well and that the US television market used to be closed off to foreign formats until the 1990s.) Nevertheless, Vertue's exceptional and atypical work as both agent and producer deserves more attention and discussion, and not just because it has been so persistently written out of much scholarly discourse on television. Having uncovered Vertue's formative, pioneering role in selling the formats for what became two seminal US television programmes, I will now pay detailed attention to her experience of producing the Upstairs, Downstairs format adaptation Beacon Hill for CBS.

\section{The Appeal of US Television Production to British Personnel in the 1970s}

Having sold Upstairs, Downstairs to London Weekend for Associated London Films in 1970, and with the export gathering acclaim and ratings success for PBS, Beryl Vertue unsurprisingly also sold the format to the period drama for production company Sagitta Productions to CBS in 1974. Crucially, however, she decided, encouraged by Robert Stigwood, to go to America and produce the format adaptation herself. She explains that one reason that attracted her to do so was that:

you couldn't be an independent producer in the UK; there was no such thing; you were an employee of the BBC, or ITV. So, I went from agenting, and then when I went to Robert Stigwood, [...] I started to think I should try and make programmes in America and try to make them for the American market [...].

\footnotetext{
${ }^{29}$ See Newberry, How a super secretary. Newberry's article begins as follows: 'Beryl Vertue is an attractive, blue-eyed blonde with winning ways and a wealthy, well-groomed look about her. The sort of woman, you feel sure, who enjoys a leisurely life centred around coffee mornings, charity fetes on the vicarage lawn, and cocktail parties. Certainly not the type who spends her days setting up - and fighting to bring off - deals involving thousands!' (Newberry, How a super secretary) Thankfully, press coverage of Vertue went on to drop such sexism.

${ }^{30}$ Vicky Ball and Melanie Bell, Working Women, Women's Work: Production, History, Gender Introduction, Journal of British Cinema and Television, 10, no. 3 (2013), 547.

${ }^{31}$ Ball and Bell, Working Women, 549.

${ }^{32}$ Jean K. Chalaby, At the origin of a global industry: The TV format trade as an Anglo-American invention, Media, Culture \& Society, 34, no. 1 (2012), 48.
} 
It seemed to me that if you were going to take formats over, you should see if you could do it yourself.

Here, Vertue picks up on her interest in developing her career and broadening her skills set by moving into producing, referencing the broadcasting landscape and employment conditions in Britain at the time. The relative absence of an independent production sector in the UK during the 1970s was certainly noticed not only by Vertue. For example, television producer Irene Shubik has spoken about her experience of working within the boundaries of the British television market at this time, which were firmly delineated by the traditional preponderance of in-house production; a situation that would only change with the boost to independent production provided by the arrival of Channel 4 in 1982, the Peacock inquiry in 1985, and the 1990 Broadcasting Act. ${ }^{33}$

Not only this, but British television production during the 1970s was further marked by the fact that individual producers did not have equity rights for the programmes they created and developed; '[a]lmost everything was done 'in house' with the companies paying the salaries of the creative staff and owning the rights to their work. ${ }^{34}$ This meant that creative staff faced no personal financial risk, but would not gain rewards beyond their wages; a situation that did not change until long after the independent production sector had been opened up, when the 2003

Communications Act finally shifted ownership of programme rights to independent producers. This situation was dissatisfying to many in the industry, and high-profile expressions of such frustrations can be found in a number of MacTaggart Lectures delivered at the Edinburgh International Television Festival. ${ }^{35}$ Such frustrations were felt especially keenly by the type of individual eager for a challenge, who would be precisely the kind more likely to venture abroad, such as Beryl Vertue. Given these circumstances, and the fact that the 1970s was a decade in which Britain was undergoing post-industrialisation recession, inflation and industrial unrest, it is hardly surprising that working in US television was an attractive proposition promising opportunities and rewards where British television production may have appeared stagnant. This proposition was taken up by a number of British television individuals, including Vertue. ${ }^{36}$

Just as the already mentioned USA-to-UK movement of personnel in the 1950s was engendered by the dovetailing of the arrival of ITV in the UK with McCarthyist blacklisting, so the UK-to-USA labour flow during the 1970s was also a historical moment in which a 'fascinating complex of transnational forces came together' ${ }^{37}$ One important reason why the USA was an attractive proposition for British television staff at the time is located within the US broadcasting landscape, specifically that this was one moment during the development of the financial interest and syndication (fin-syn) rules in which independent production in the USA received

\footnotetext{
${ }^{33}$ Irene Shubik, Play for Today: The evolution of television drama, second edition (Manchester, Manchester University Press, 2000).

${ }^{34}$ Shubik. Play for Today, 184.

${ }^{35}$ See, for example, Verity Lambert, The James MacTaggart Lecture 1990: Deregulation and Quality Television, in Television Policy: The MacTaggart Lectures, ed. Bob Franklin (Edinburgh, Edinburgh University Press, 2005).

${ }^{36}$ See Les Brown, Two British TV Directors Set Up Shop in U.S., The New York Times, January 19, 1978, C19.

${ }^{37}$ Michele Hilmes, The 'North Atlantic Triangle': Britain, the USA and Canada in 1950s television, Media History, 16, no. 1 (2010), 41.
} 
considerable (although not unproblematic) support. ${ }^{38}$ With the introduction of the finsyn rules in 1970, limits were placed on the amount of prime-time programming the networks could produce themselves, and independent production companies received an incentive in the form of the long-term rights to programmes they produced, which meant that after the challenges of deficit financing they could reap the rewards of successes. Vertue describes her experience of this as follows:

There was a federal ruling that no broadcaster, no network could have their own production company, and therefore there was an enormously strong and clever, creative, independent production community in America. And it meant you talked direct to the network, to the head of this or that. Now it's different, because [during the 1990s] they changed that ruling and said networks could have production companies. [...] What it has meant for an independent company is that there are myriads of people to get through, to get an answer to something.

So, Vertue's move across the Atlantic was marked by the dovetailing of the development of both the equity rights during the period before the independent production boom in the UK, and the fin-syn rules in the USA. It was motivated by the prospect of financial benefits both in terms of salary and additional pecuniary rewards, although not entirely so: what further emerges in her account is a sense of her appreciation of the USA as a dynamic working environment at the time. This chimes with the comments Tony Garnett has made about his experience of working in the USA during the 1980s. ${ }^{39}$ As Lacey has noted, 'it may seem an odd decision for someone $[\ldots]$ so out of sympathy politically with American capitalism and the commercial film-making ethic in particular [...] to decamp to Los Angeles' ${ }^{40}$ Nevertheless, Garnett has more than once praised 'the energy, the openness and the "can do" he experienced there. ${ }^{41}$ The transatlantic movements by both here were marked by an experience and enjoyment of the US production sector as a space of freedom and opportunity in a way that accords with dominant US selfconceptualisations of the American Dream, and significantly differs from those earlier transatlantic movements during the McCarthyist blacklisting of the 1950s.

Whilst Vertue's and Garnett's careers developed rather differently until the point when each went to work in the USA - Garnett already had an extensive track record as a producer, whilst Vertue's experience was rooted in her work as an agent what they have in common is that their time in America was, in Vertue's words, 'very helpful' when setting up their independent production companies following their return to the UK. As Vertue confirms: "That way of working proved valuable to me. It was second nature; I thought, "I've done it that way before."' Similarly, setting up World Productions after his return from the USA, Garnett's time in the USA had proved to be 'invaluable in the new context that faced him', namely the changed British broadcasting landscape. ${ }^{42}$ That Hartswood Films and World Productions were

\footnotetext{
${ }^{38}$ See Matthew P. McAllister, Financial Interest and Syndication Rules, in Museum of Broadcast Communications Encyclopedia, ed. Newcomb.

${ }^{39}$ Garnett worked there in films, but Shepherdson points out the impact cable television had on film production in the USA at the time. K. J. Shepherdson, Pragmatic Radicalism: Trans-Atlantic Experiences and Influences in the Work of Tony Garnett, Critical Studies in Television, 2, no. 2 (2007), 115.

${ }^{40}$ Stephen Lacey, Tony Garnett (Manchester, Manchester University Press, 2007), 116.

${ }^{41}$ Garnett cited in Shepherdson, Pragmatic Radicalism, 115.

${ }^{42}$ Lacey, Tony Garnett, 121.
} 
helmed by individuals with transatlantic production experience and thus knowledge and skills concerning sets of practices, risks and rewards, helped these two production companies in a newly and increasingly competitive production environment.

\section{Producing Beacon Hill: Knowledge, Difference and Productive Otherness}

Beryl Vertue's experience of producing in the USA is significantly centred around the Upstairs, Downstairs adaptation Beacon Hill, a period drama set in Boston, focusing on a wealthy family of first generation Irish immigrants and their domestic staff. As my analysis will show, it is a programme with a fascinating production history that interestingly links to issues concerning knowledge, difference, Otherness, 'quality' television and failure, as well as the 1970s US television landscape. It represents an interesting occurrence in the 'transformative moment' during the 1970s that Mittell has identified in relation to the 'ascendancy of the quality audience that is still the primary target of network programming and advertisers'. ${ }^{43}$ However, with the exception of (brief) attention by chiefly Miller and Pfefferman, Beacon Hill has been somewhat overlooked and neglected within scholarly debates. ${ }^{44}$ period:

Vertue describes how she made some key decisions during the pre-production

Actually, what I'd never done - and I didn't say this to anybody - I'd never produced anything, because you couldn't [in the UK]. So, I got rushed round by different studios: 'Would you like to come and shoot here? Or here?' And I'm coming in and looking at all these places, without necessarily knowing why one was better than the other [...] and when we came to the casting, I didn't know anybody, so therefore, in the auditions we looked for someone who was really talented and really right for the part. Consequently, we ended up with ever such a good cast of people who, it turned out, weren't very known at all; we didn't have any 'names' in there. So, I gradually seemed to get, which was quite fortunate, known as the person who likes to cast people who aren't very well known.

She further recounts how:

I thought, we should set this in Boston and we could shoot it in New York, because there's all those actors in the theatre, not knowing that no-one had shot drama in New York for 15 years. So, of course everyone went, 'Good Lord! Drama is coming back to New York!' There were lots of people fussing and being very pleased to see that you were bringing production business to New York. Then we did it multi-camera and everyone went, 'Good Lord! It's multi-camera! How amazing is that!' Well, of course it wasn't amazing to me, because that's what we did in England. We didn't have $35 \mathrm{~mm}$ cameras to do drama, there's no way you did that. We did it on multi-camera and if you went outside you shot that bit and then you had to wind it all up. So that was,

\footnotetext{
43 Jason Mittell, Television and American Culture (Oxford, Oxford University Press, 2010), 82-83.

${ }^{44}$ See Miller, Something Completely Different, 163-164; and Richard Pfefferman, Strategic Reinvention in Popular Culture: The Encore Impulse (New York, Palgrave Macmillan, 2013), 73 and 77-78. Pfefferman's consideration represents the most sustained attention to Beacon Hill in published scholarship thus far. Attributing the programme's cancellation to textual shortcomings and a lack of resonance with the US cultural context of the 1970s, his discussion - unlike Miller's work - fails to consider industrial/institutional context, especially the significance of the differences between network and non-network television.
} 
unwittingly, doing something where everyone went, 'How amazing is this!' and I was doing what we were used to over here; it was quite funny really.

Several interesting issues arise from her words, beginning with notions of quality: because Vertue was unfamiliar with the production environment and the then dominant practices, she thought to shoot Beacon Hill in New York, on videotape and multi-camera style. This links Beacon Hill to both British quality traditions and discourses as well as the 'first golden age' of American television drama. It connects the programme simultaneously to notions of theatre and theatricality (via the use of multi-camera production methods and Vertue's interest in NYC actors) and soaps, as she relied on her line producer to find the crew, who had extensive soap experience 'because they did the big daily soaps in New York.' With its theatre-based cast and soap-based crew, as well as its links to traditions and discourses on both sides of the Atlantic, Beacon Hill complicates a number of evaluative hierarchies and binaries, thus making an interesting addition to the ongoing debates on television and quality (to which I will return later).

Secondly, Vertue's comment about the (lack of) use of $35 \mathrm{~mm}$ production requires qualification, for it actually downplays the foresight and business acumen she had demonstrated while representing Sagitta Productions during early negotiations with London Weekend over Upstairs, Downstairs. She pursued initially the possibility to shoot the series on film, and then to convert part of the series to film. The reason for this was that Vertue, with her eye on the international market following the successful format sale of Till Death Us Do Part, was hoping to sell the series abroad, keen to have at least some material on film to use for a 'promotional sales campaign to America', as she put it in a letter to her negotiating partner, London Weekend's Stella Richman. ${ }^{45}$ Here, Vertue's account is interestingly problematised by her own - earlier, written - words.

Then, Vertue's approach to producing Beacon Hill raises notions of knowledge and difference. It was because Vertue herself did not have knowledge of the then dominant production practices and processes in the USA, that she took what were considered to be unconventional decisions. Indeed, although it did not show up on screen, perhaps the most unconventional decision she took while producing Beacon Hill was to set up a meeting:

I thought I'll ask if I can meet William Paley, who created CBS; that was like saying, 'I think I'll just see if I can speak to God!' [...] I asked could I meet him, rang his office, the meeting got arranged. The rest of the building were astounded! A: because I'd asked to meet, and B: because he'd agreed to meet. There were people at CBS who'd been there a hundred years who'd never met him and were not likely to, so the whole building waited with bated breath for me to have this meeting. It was extraordinary. ${ }^{46}$

Speaking of her then lack of knowledge from a point of hindsight, Vertue adds:

\footnotetext{
${ }^{45}$ Vertue cited in Marson, Inside Updown, 29.

46 This extraordinariness is confirmed by Lear's comment that he never directly heard from chairman Paley during his first eight very successful years of producing shows broadcast on CBS. Lear, Even This, 317. Bedell furthermore has noted that 'Silverman often lacked direct access to Paley, who habitually cut himself off from day-to-day business at CBS.' Bedell, Up the Tube, 99.
} 
In a way, I broke lots of rules because I didn't know they were there. And that's another important thing: if you see an obstacle you'll think, 'How can I get around that?' But if you don't even know it's difficult, and I didn't know it was difficult [...], it didn't occur to me that it was difficult, or that nobody had done it. All of those things really don't come into your head, and when you get much more experienced - as indeed I am now, because I've been doing it for so long - you have to try not to let your knowledge of rules get in the way. As she points out, a lack of knowledge - blissful ignorance, if you like - can be creatively freeing, while knowing the structures, practices and processes inevitably shapes, and potentially constrains, production work. Indeed, the difference of her knowledge became a potent potential currency for her while she was in the USA: I think people were quite interested in [me being different], and also because these two formats had worked brilliantly well, I went through a period where I thought that people thought, 'What is she thinking about now? What does she know?' It was good, you gained respect because you'd had two good ideas and it had all worked so well, so it was like, 'Have you got any other thoughts?'

On the basis of not knowing any different, Beryl Vertue took unusual decisions that were informed by and reflexively highlighted her difference. Such difference, whereby a distinct vantage point is provided by the fact that the local dominant conventions and operating norms have not become naturalised and selfevident, potentially marks any transatlantic exchange. But Vertue's difference is noticeably dissimilar to that of, for example, those individuals from America working pseudonymously for British television during the 1950s, such as writer Ring Lardner, $\mathrm{Jr}$, for their 'American identity and experience [...] necessarily remained covert, constrained by cold war politics as well as fears of 'Americanization' of British commercial television'. ${ }^{47}$ Similar to broadcaster Alistair Cooke, Vertue's identity and that of her programmes were overtly different: where Lardner, Jr and his peers were, as Neale has pithily put it, “"un-American” Americans,' Vertue was 'very British', ${ }^{4}$ As a woman and a foreigner producing drama for a US network during the 1970s, she was unmistakeably Other.

In fact, Vertue quite deliberately kept her Otherness heightened by not actually permanently settling in the USA, enjoying that the normal rules did not apply to her and the productive benefits this brought:

It was unusual being a woman, and it was unusual being British, and it was unusual that I didn't live there; you'd come in, do some meetings and leave, and it seemed to surprise people and catch them on the hop a little bit. [...] I think they used to be quite impressed sometimes when you'd achieved this when you didn't live there, and it was actually an advantage I think. Much later there was a year when I lived there most of the year for tax reasons. [...] I think it was the most unproductive year I had: once you were there you had to wait for the meetings like everybody else. I found their worries and anxieties about things started to get to me in the end about why things couldn't happen, as opposed to why things could. [...] Better to dash in, do it, leave.

\footnotetext{
${ }^{47}$ Hilmes, North Atlantic Triangle, 39.

${ }^{48}$ Neale, Pseudonyms, Sapphire and Salt, 245.
} 
This status as Other, which is (covertly or overtly) present in any transatlantic exchange, meant not only that Vertue was likely to be doing things differently, but also that, as her experience shows, both the people she was directly working with and the wider industrial environment were more willing to accept her different approach and suspend or amend their usual procedures. Given that the methods of the first golden age of US television drama had long been supplanted by filmed production in Hollywood, it is questionable whether a US producer would have thought of, let alone been given the go-ahead, to produce a programme like Beacon Hill the way Vertue did. For, in the terms of Schein's theory on organisation culture,

The culture of a group can now be defined as a pattern of shared basic assumptions that was learned by a group as it solved its problems of external adaptation and internal integration, that has worked well enough to be considered valid and, therefore, to be taught to new members as the correct way to perceive, think, and feel in relation to those problems. ${ }^{49}$

Members of a local group, such as the US television production sector here, learn and become immersed into shared attitudes, norms and practices that they expect from one another in a way that they do not from an outsider; and this leaves a gap that can be productively exploited by transatlantic individuals such as Vertue, who sustained and widened the gap by not settling there and thus constraining her immersion.

There are resonances between Beryl Vertue's productive Otherness and the experiences of further transatlantic individuals, such as Sydney Newman, who arrived from North America at the BBC in the early 1960s, where he instituted significant changes, including restructuring the drama department. ${ }^{50}$ Again, not only would a British broadcasting executive have been less likely to do such things, but perhaps would also have encountered more resistance. While Newman, as Hilmes notes, attracted some internal criticism, it is conceivable that such criticism would have been more pronounced if 'one of us' had instigated those changes ${ }^{51}$ Less inured to the local dominant conventions and with fewer trepidations to go after 'sacred cows' (be that because of a lack of knowledge or personal investment), Vertue and Newman were in demand precisely because of their difference and the change it could bring. The BBC Newman joined was having to contend with successful competitor ITV and therefore willing to have an outsider (literally, a foreigner) come in and 'shake things up'. Vertue produced Beacon Hill for CBS at a time when the latter had been the number one network and keen to find ways to bolster its lead, especially in the face of developments, including the rise of cable, that would alter the US television landscape considerably and dismantle the entrenched oligopoly that had dominated US broadcasting for so long. 52

\section{Fred Silverman, Quality Programming and Relative Failure}

However, Otherness is bound to encounter and cause some friction. Beryl Vertue experienced difficulties with CBS, both before and while Beacon Hill was broadcast,

\footnotetext{
${ }^{49}$ Edgar H. Schein, Organizational Culture and Leadership, third edition (San Francisco, Joseey-Bass, 2004), 17.

${ }^{50}$ See Hilmes, North Atlantic Triangle, 44-45.

${ }^{51}$ Hilmes, North Atlantic Triangle, 45.

${ }^{52}$ At approximately the same time, as Weissmann has noted, NBC was beginning to turn towards programming with a theatrical aesthetic (such as Captains and the Kings, 1976); only it did so not from a position of strength, but of crisis as the least popular network. Elke Weissmann, Transnational Television Drama: Special Relations and Mutual Influence between the US and UK (Houndmills: Palgrave Macmillan, 2012), 78-79.
} 
intertwining her transatlantic experience with some of the 'few great men' of US television history already mentioned. She recounts how her pre-production period unexpectedly got shortened to a mere two months:

[Fred Silverman] was always nervous of it. I don't think he could get the hang of it at all, because it was so unusual; and also, I wasn't as prepared as I should have been, I should have had a story editor and I didn't. [...] It was because they did approve it to go on the air, and they had a sort of an airdate, and then Fred Silverman got very anxious about how it was going to go, and he thought, 'I know what I'll do, I'll start earlier than everybody else!' And he suddenly moved it forward three, four weeks, which was colossal. ${ }^{53}$

The shortened pre-production period caused problems for the scripts that were reinforced by the fact that this was the first direct production experience for Vertue. Caught out by the change in transmission date, she had no developed series 'bible' setting out the narrative arcs and continuities of settings and character, so crucial for the management of long-running programmes. (CBS had ordered a 2-hour pilot and twelve hour-long episodes, with an option to extending the show to 26 episodes for at least the next seven years.) Moreover, Vertue experienced resistance and delay when wishing to invite Upstairs, Downstairs producer and writer John Hawkesworth to come over and help out as a script advisor. ${ }^{54}$

It was then-Vice President of Programs for CBS-TV Fred Silverman who interfered so noticeably (and to Vertue noticeably negatively) in the development of Beacon Hill, pulling the pilot's transmission date forward to the 25 August 1975 to establish an audience for the programme before the start of the fall season. Silverman's involvement further links the programme and Vertue's transatlantic experience to issues concerning quality. For while CBS had been the dominant network since the 1950s, it was Silverman who (together with CBS President Robert Wood) made the decision to implement the 'rural purge' in the late 1960s and early 1970s. Here, ratings-winners such as Green Acres (CBS, 1965-1971) were cancelled in order to bring in 'relevant' shows such as All in the Family, in the network's attempt to change the demographic profile of its audience into the advertiser-friendly demographics of the younger, urban and more affluent and, as Mittell has noted, maximise profits from its owned-and-operated stations, which were in major cities. ${ }^{55}$ With its evident links to quality notions of the kind that were attracting critical and commercial success for British import series Masterpiece Theatre on PBS, Beacon Hill must have seemed like a good way to try and extend CBS's more critically acclaimed programming to original dramatic output; to tap into a current of (Britishinflected) quality drama (and perhaps also the bicentennial mood); and to target the urban, upscale viewers who were tuning into Masterpiece Theatre. ${ }^{56}$

As an added bonus, Beacon Hill was also relatively inexpensive, with a budget of $£ 86,000$ per hour. This was nearly four times more than the budget for its British progenitor Upstairs, Downstairs, allowing for some location shooting. However, it

\footnotetext{
${ }^{53}$ Silverman's decision was possibly informed by the erroneous assumption that multi-camera style shooting on tape would or should be able to accommodate the lesser amount of available time.

${ }^{54}$ For details, see Les Brown, Briton Arrives to Help CBS With Ailing 'Beacon Hill', The New York Times, October 20, 1975, 67.

${ }^{55}$ Mittell, Television and American Culture, 82-83.

${ }^{56}$ CBS had scored critical praise for its BBC import The Six Wives of Henry VIII in 1971.
} 
was not especially high by then US television production standards, and certainly not given that CBS was strongly promoting Beacon Hill as a quality show. (Here, CBS took account of the tendency by critics at the time to bestow critical praise on programmes with theatrical aesthetics. $)^{57}$ Compare it to another mid-1970s quality network drama, the acclaimed Roots (ABC, 1977): structurally indebted to British television drama, Roots had an overall budget of $\$ 6.6$ million for its eight episodes. So, Beacon Hill must have been an attractive proposition given its likely appeal to upscale demographics and critics via inexpensive quality discourses. (Bedell has pointed out that CBS had been showing 'an unwillingness to spend enough money on programming', with Silverman's development budget having been cut for the 1974-75 season. $)^{58}$

However, as Vertue highlights, Silverman was nervous about Beacon Hill. This was partially fed by concerns that not only had this kind of drama not been shown on CBS (or the other networks) for a long time; but perhaps also that it was with the move away from prestigious New York-based studio drama during the 1950s that CBS had assumed its place as the dominant network, which Silverman was of course loath to lose. ${ }^{59}$ Silverman's response furthermore links to the ambivalent attitude at the time by the networks towards serialised storytelling. As Newman and Levine have pointed out, the networks liked the flexibility afforded by episodic storytelling and were very aware of 'the failure of the serialized dramas that debuted after Peyton Place [(ABC, 1964-1969)]' ${ }^{60}$ However, with the success of Rich Man, Poor Man (ABC, 1976), 'a specific kind of serialization (adapted from a novel, historically oriented, limited run) became a television institution'. ${ }^{61}$ Rich Man, Poor Man was a miniseries 'centered on a family, [which] had historical sweep [...], and dealt with cultural delineations of class. ${ }^{, 62}$ So, there were noticeable textual similarities with Beacon Hill. However, the former was cast 'with familiar faces from American film and television' and did not get subjected to a shortened pre-production period by Silverman (who, partly out of frustration at his felt lack of decision-making power, had left CBS in May 1975 to become head of ABC Entertainment). ${ }^{63}$

Both Roots and Rich Man, Poor Man, which together helped establish 'the British-based serialized drama in both its historical and literary forms in the United States,' were also subject to Silverman's decision-making. ${ }^{64}$ Silverman insisted that Rich Man, Poor Man follow the serialised, short-run structure established by

\footnotetext{
${ }^{57}$ Weissmann, Transnational Television Drama, 167. Reviews for Beacon Hill were not unanimously positive; see John Kifner, An Irish Family on Beacon Hill? CBS Terms It 'Poetic License', The New York Times, September 3, 1975, 39.

${ }^{58}$ Bedell, Up the Tube, 104.

${ }^{59}$ For a discussion of CBS's complex relationship to issues of quality programming in the early decades of television, see William Boddy, Building the World's Largest Advertising Medium: CBS and Television, 1940-60, in Hollywood in the Age of Television, ed. Tino Balio (Boston, Unwin Hyman, 1990).

${ }^{60}$ Michael Z. Newman and Elana Levine, Legitimating Television: Media Convergence and Cultural Status (New York; London: Routledge, 2012), 85. Newman and Levine note that further unsuccessful attempts at serialized drama during the 1970s, including Beacon Hill, only served to reinforce the network mindset.

${ }^{61}$ Newman and Levine, Legitimating Television, 84.

${ }^{62}$ Miller, Something Completely Different, 165.

${ }^{63}$ Miller, Something Completely Different, 165.

${ }^{64}$ Miller, Something Completely Different, 167. For a comprehensive discussion of the roots of the American miniseries, see Weissmann, Transnational Television Drama, 108-116.
} 
programmes such as Beacon Hill progenitor Upstairs, Downstairs. ${ }^{65} \mathrm{He}$ was also involved in Roots' influential scheduling:

Fred Silverman scheduled Roots for the last week in January because he was not convinced that it would do well enough in the ratings to mandate its broadcast during the network "sweeps" period in February; he chose to present it over eight consecutive evenings both to heighten "the impact of the work" and to minimize any ratings damage that might be done by spreading it out over two months. ${ }^{66}$

Thus, while Silverman is associated with some scheduling decisions that can be understood as enabling quality programming, his apprehensions for Beacon Hill resulted in an interference from which the programme could not recover. ${ }^{67}$

Crucially and unsurprisingly, however, it was ratings that had the determinant effect on Beacon Hill and Beryl Vertue's transatlantic experience of producing it. The programme dropped from an initial high of $42 \%$ to an average of $22 \%$ in its Tuesday evening slot, below the $30 \%$ prime time share threshold for programmes then. ${ }^{68}$ Beacon Hill's ratings were considerably higher than British imports were achieving on niche broadcaster PBS, but deemed not good enough for leader CBS in the (already numbered) days of regular mass audiences for the US networks. Furthermore, given that Masterpiece Theatre has tended to be older-skewing, it is possible that the profile of the Beacon Hill audience did not quite fit CBS's demographic preference for younger viewers, and thus the programme in some ways suffered a similar fate to that of the rural shows a few years earlier. Perhaps Beacon Hill narrowly missed the mark in terms of both its overall ratings and specific audience demographics. (Certainly, the promotional hype and immense pressure of expectation bearing on the programme - one CBS print advertisement proclaimed that 'NEVER BEFORE IN TELEVISION HISTORY HAS A SHOW CREATED THIS KIND OF ADVANCE EXCITEMENT!' - could not have helped.) A number of factors complexly intertwined, and contending with a general ratings decline, CBS would have been less inclined to continue with a programme that was not an indisputable success. ${ }^{69}$

So, Beacon Hill got cancelled mid-season. As Vertue puts it:

The figures were good, but not as good as the other two networks. [...] So they did, after a series, take it off, because it didn't have as big an audience as the other two networks. On the other hand, it had an audience, when we left,

\footnotetext{
${ }^{65}$ Miller, Something Completely Different, 165.

${ }^{66}$ Miller, Something Completely Different, 233, note 91.

${ }^{67}$ Silverman is an interesting figure in terms of quality television programming, for he is associated with, amongst others, CBS' 'rural purge', the scheduling of ABC's Roots and NBC's Hill Street Blues, the successful hammocking of $M * A * S^{*} H^{*}$ between All in the Family and The Mary Tyler Moore Show on CBS, as well as ABC's move to sexualised 'jiggle TV' during the 1970s. See Miller, Something Completely Different; and The Columbia History of American Television, ed. Gary R. Edgerton (New York, Columbia University Press, 2007. Furthermore, having previously turned down Sanford and Son for CBS, Silverman interfered in Vertue's transatlantic production work once more at ABC, when changing the set-up of It's A Knockout format adaptation Almost Anything Goes. See Potter, The Rise and Rise, 52.

${ }^{68}$ See Brown, Briton Arrives to Help, 67.

${ }^{69}$ See Les Brown, Why CBS Killed New 'Beacon Hill', The New York Times, October 28, 1975, 35.
} 
of 23 million and I remember thinking at the time, how strange actually to be a failure with 23 million people. ${ }^{70}$

In the light of these figures and the shortened pre-production period, Silverman's promotional rhetoric for the premiere of Rich Man, Poor Man is certainly noteworthy: 'What we really want to prove is...that in the long run there is an audience for this kind of drama. [...] I think the show is a TV landmark. It will be what Beacon Hill should have been. ${ }^{71}$ Silverman also commented that Beacon Hill might not have got cancelled if he had still been at CBS to deliver the programme schedule in the fall. ${ }^{72}$ This is a noticeably self-serving view, given that he would subsequently 'rush series on the air - and then off again at the first hint of ratings failure' when working at $\mathrm{NBC}^{73}$

The relative failure encountered by Beryl Vertue links to other transatlantic experiences of lack of success, frustration and termination concerning the economic realities of US television. For example, having wanted to work in Hollywood for a long time, Dalek-creator Terry Nation ultimately 'disapproved of the domination of the US film industry by accountants and was unable to sell a new television format in the United States. ${ }^{74}$ The most high-profile criticism stemming from such transatlantic movement has probably been articulated by Michael Grade. Having worked as president of independent production company Embassy Television (an offshoot of Joseph E. Levine's Embassy Pictures) in the early 1980s, Grade notoriously described his time in the USA as 'selling crap to assholes' at the Edinburgh International Television Festival in 1983. A year later he wrote an article for a British newspaper in which he attacked 'the rich killing fields of US television' for the dependence by executives on

the mumbo-jumbo jargon of research, concept testing, TVQ (an allegedly outlawed formula for assessing performers' acceptability to viewers - a blacklist if you ask me), ratings, demographics and yet more research. ${ }^{75}$ Given the strength of his reproval, it is worth noting that Grade, a known selfpublicist with a penchant for snappy soundbites, was at the time in the process of moving back to the UK where he took up the post of controller of BBC1.

With its cancellation and - with the exception of a repeat of two episodes on HBO in 1976, as noted by Mullen - subsequent disappearance from sight, with no DVD release to date, Beacon Hill has not become one of the culturally significant shows in US television history the way that All in the Family and Sanford and Son

\footnotetext{
${ }^{70}$ Vertue would have further experience of such relative failure: she produced Men Behaving Badly (ITV/BBC1, 1992-1999) which, as she explains 'began on ITV but moved across to the BBC after ITV dropped it because the ratings weren't high enough. It was at the time when every peaktime ITV programme had to achieve an audience of at least 10 million viewers. If it got less, you were regarded as a failure.' Vertue cited in Stephen Clarke, A Week in the Arts, The Daily Telegraph, May 27, 1995, A3.

${ }^{71}$ Silverman cited in Miller, Something Completely Different, 165.

${ }^{72}$ Bedell, Up the Tube, 187.

73 Tony Schwartz, Silverman: Caught between High and Low Roads, The New York Times, July 2, $1981,36$.

${ }^{74}$ Jonathan Bignell and Andrew O’Day, Terry Nation (Manchester, Manchester University Press, 2004), 22.

${ }^{75}$ Michael Grade, What TV in US Taught Me, The Observer, August 26, 1984, 8. He made no mention of Vertue when singling out the work of Embassy Television's co-owner Norman Lear for praise.
} 
have. ${ }^{76}$ However, as a US network format adaptation of a British drama, it remains a rare beast, located within the trajectory from British drama exports on network television in the early 1970s (especially The Six Wives of Henry VIII) to American miniseries on network television influenced by British television drama in the mid1970s (e.g. Captain and the Kings, NBC, 1976).

Beacon Hill also represents a significant point of reference in the 'blip' that Weissmann has identified concerning the shift back to a more theatrical aesthetic on US television during the 1970s. ${ }^{77}$ Moreover, it marks an interesting occurrence in the transformative moment concerning the 1970s 'ascendancy of the quality audience that is still the primary target of network programming and advertisers'. ${ }^{78}$ As such, it deserves a more prominent place in accounts of US television history more broadly, and of CBS more specifically, for Beacon Hill was a significant programme during a season that proved to be a turning point for this network. Having to contend with increasing audience fragmentation as well as a number of other structural changes to the US television industry, CBS would find itself losing its place as the number one network to $\mathrm{ABC}:^{79}$

By 1976-1977, ABC boasted seven of prime-time's top ten programs as the network took a commanding lead in the overall ratings at 21.6 to CBS's 18.7 and NBC's 18.2. The unthinkable had occurred. ABC was Bicentennial America's no.1 network, and Fred Silverman was television's latest celebrity programmer $[\ldots]^{80}$

\section{Conclusion}

This article has been interested in the ways in which US television, though in many ways a (notoriously) closed off market, has been receptive to trajectories of influence, accompanied by complex negotiations of difference and assimilation. A sizeable enough number of British television individuals have found work there across the years; and much remains to be discovered about the significance of such British stints on North American shores, and how they have impacted British television. Able to use her experience of Beacon Hill and the economic realities of US television in her subsequent production work, Beryl Vertue reflects back on her experience as follows:

When you get the commission, you don't get much lead time in the first place, and then to pull it forward, with a show of that kind as well was quite tough really. But anyway, it was an achievement to have got it on, and it was the first time a British producer had made a series for American television, for America. I quite like all those firsts.

The other firsts she is referring to here include selling the format for Till Death Us Do Part; and she was not only the first to sell formats for British fiction programming to the USA, but more crucially has also had the most significant cultural success in the format trade. Moreover, Vertue was working as a producer in the USA at a time when being British and being a woman each was unusual for that position, and she has

\footnotetext{
${ }^{76}$ Megan Mullen, The pre-history of pay cable television: An overview and analysis, Historical Journal of Film, Radio and Television, 19, no. 1 (1999), 51.

77 Weissmann, Transnational Television Drama, 80.

${ }^{78}$ Mittell. Television and American Culture, 82-83.

${ }^{79}$ For details of these structural changes, see Gary R. Edgerton, A Great Awakening: Prime Time for Network Television - 1964-1975, in The Columbia History of American Television, ed. Edgerton.

${ }^{80}$ Gary R. Edgerton, 'The Sky's the Limit: Satellites, Cable, and the Reinvention of Television - 19761991' in The Columbia History of American Television, ed. Edgerton, 294.
} 
worked since with each of the three major US networks.

Following Reeves' proposition that 'it is at the level of series creation that questions of authorship become a pertinent critical concern', Beryl Vertue's input and involvement in a range of programmes on both sides of the Atlantic certainly deserves attention. ${ }^{81}$ She has to date received recognition that includes the BAFTA Alan Clarke Award for Outstanding Contribution to Television (2004), a Royal Television Society Lifetime Achievement Award (2012) and a CBE for Services to Television Drama (2016); and a much more prominent place in scholarly discussions on transatlantic format adaptations, and British and American television more broadly, is long overdue. This article has endeavoured to facilitate more scholarly engagement with this significant figure, firstly by uncovering her formative role in selling the formats for what became two seminal US television programmes, and secondly by exploring her fascinating experience of producing format adaptation Beacon Hill for CBS. Approaching interviewing as a way to 'allow participants to shape research results, rather than those participants being merely tools used by researchers to prove a point', the article has demonstrated that practitioner discourse is a rich resource that can open up new fields of enquiry and generate new knowledge. ${ }^{82}$ Beryl Vertue has done unusual, unconventional things without necessarily setting out to do so - as she puts it in relation to format selling: 'I didn't think I was being a pioneer, I just thought, 'That seems a good idea: I'll sell it there, I'll sell the format of it', because you couldn't sell the programme.' Thus, bestowing on Beryl Vertue the title of unwitting pioneer seems fitting, for it recognises, emphasises, but not over-stresses her agency as she has operated within complex relationships, networks and contexts.

\section{Acknowledgments}

I thank Beryl Vertue for generously providing her time and thoughts, as well as Jonathan Bignell for his helpful comments on a draft of this article.

(11,975 words)

\footnotetext{
${ }^{81}$ Jimmie L. Reeves, Rewriting Culture: A Dialogic View of Television Authorship, in Making Television: Authorship and the Production Process, ed. Robert J. Thompson and Gary Burns (New York, Prager Publishers, 1990), 151.

${ }^{82}$ Brett Mills, After the Interview, 151.
} 